\title{
Soft Tissue Sarcoma of the Trunk and Extremities pT4 TNM Finding v8
}

National Cancer Institute

\section{Source}

National Cancer Institute. Soft Tissue Sarcoma of the Trunk and Extremities pT 4 TNM

Finding v8. NCI Thesaurus. Code C136688.

Soft tissue sarcoma of the trunk and extremities with tumor measuring more than $15 \mathrm{~cm}$

in greatest dimension. (from AJCC 8th Ed.) 